\title{
The "cause of Jesus" (Sache Jesu) as the Canon behind the Canon ${ }^{1}$
}

\author{
Andries G van Aarde \\ Department of New Testament Studies \\ University of Pretoria
}

\begin{abstract}
God, and not the Bible as such, is the church's primary authority. Jesus of Nazareth is the manifestation of God in history. In a post-Aufklärung environment one cannot escape the demand to think historically. To discern what could be seen as the "ground" of faith, one needs to distinguish the "proclaiming Jesus" from the "proclaimed Jesus", though these two aspects are dialectically intertwined. This dialectic can be described as the "Jesus kerygma" or the "cause of Jesus". The aim of this article is to argue that if Christians focus only on the church's kerygma they base their ultimate trust upon assertions of faith, rather than upon the cause of faith. The dictum that the cause of Jesus is the canon behind the canon is explained in terms of the distinction between "fides qua creditur" and "fides quae creditur", and postmodern historical Jesus research.
\end{abstract}

\section{INTRODUCTION}

I am on record as having said that I "do not consider the canon as the primary authority for the church" and that I "call for a return to the search for the cause of Jesus (a principle of continuation between the historical Jesus and Paul's understanding of Jesus) as the canon behind the canon (the principle behind the canon)."2 These words are not exactly my own, but I am responsible in the theological debate in South Africa for

\footnotetext{
1 This article is dedicated to Prof Dr G M M Pelser who retired on January 31 st, $200 \mathrm{l}$ as Professor of New Testament at the University of Pretoria.

2 "Hy [A G van Aarde] beskou nie die kanon as die eerste outoriteit van die kerk nie. Hy bepleit 'n terugkeer na wat hy beskryf as die soeke na die Jesus-saak (as kontinuiteitsbeginsel tussen die historiese Jesus en Paulus se verstaan van Jesus) as die kanon agter die kanon (die beginsel van die kanon)" (Van Wyk 1999:117)
} 
coining the expression "the cause of Jesus as the canon behind the canon" and for saying that "the Bible is not the primary authority for the church". The aim of this article is to explain these views.

Both the expressions used above - "the cause of Jesus" and "canon behind the canon" - originated in the theological thinking of the German New Testament scholar Willi Marxsen. According to Marxsen (1968a:284), the New Testament (and for that matter, the Bible) should not be put "in the place of Jesus as the revelation". I accede to Marxsen's view that Christianity is a religion based on a historical person and not on a book as such. William Thompson (1985:115), building upon the insights of philosophertheologians Paul Ricoeur and David Tracy, says:

Christianity is not a religion of a book, but of a person, Jesus [as] the Risen One. But the Jesus event has left us "traces" of itself in the New Testament, and it is chiefly to this "text" that we must turn for "normative codification" of the Jesus event. That we go to Jesus through the biblical text is finally rooted in our tradition-bound character. Like all other things human, Christianity is an historically-mediated religion.

For Christians, Jesus of Nazareth is God's becoming event for humankind. Christians met God in their encountering of Jesus and still meet God in their encountering of the stories about Jesus. In other words, God became God for people through Jesus' interaction with them. The Jesus event yields to this "interaction" - the Sache Jesu that began in the life of the pre-Easter Jesus and continues in the life of the post-Easter Jesus through the mediation of the kerygma, a cause that circles wider and farther than firstcentury Christianity.

Although God is God for Christians today through the historically mediated witness in Scripture, God remains for the church its primary authority, and not the Bible as the witness of the Jesus event as God's salvation for humankind. Like Judaism, Christians believe that God is the creator and that God is totally unlike, but not separated from, creation. Although God is not an object like anything else in creation and is, therefore, not to be objectified, God's becoming event in Jesus of Nazareth is historically discernable. Jesus is the manifestation of God. Jesus is the observable face of God. By 
putting their trust in God's event, the followers of Jesus (labeled by outsiders as “Christians") (cf Pilch 1997:119-125) eulogized Jesus, specifically after his death, by means of honorary titles and faith assertions. These adorations became dialectically integrated with the Jesus traditions that were transmitted by the different Christian factions.

Critical scholarship, historically seen, could decipher to a remarkable extent these attestations from the words and sayings of Jesus himself. Both the authentic words and deeds of Jesus and the faith assertions by followers, the two-in-one, constitute the Jesus kerygma which forms the basic support for Christians over centuries to live by the cause of Jesus, which is God's presence for us. Historical criticism serves us, the people of later generations who are not witnesses of the historical Jesus event itself, but only have these "codified" faith attestations to rely on, so that we may participate in the cause of Jesus and thus in God.

\section{FIDES QUA CREDITUR OR FIDES QUAE CREDITUR}

I know it is risky to say so, but one could call this participation "faith." However, faith, subjectively seen, is not related to the believer's mind or deeds alone, but is seated in the heart. And yet faith does not originate because of a human's heartfelt emotions without something "out there" that has caused the Christian believer to put her or his ultimate trust in God's event through Jesus. Objectifying this cause, or articulating it in terms of faith assertions, is already the activity of head and hand. But when this is done, viz. the act of enunciating intelligible faith, it seems that human beings are tempted to put their ultimate trust in the assertions of faith, that is, in the act and ratio of others, rather than in the cause of faith. It is a matter of faith as belief against faith which is to be believed, a belief in the belief of others. The latter can already be found, among other documents, in the second-century New Testament writing Jude (verse 3). In Latin, this distinction may be alluded to as fides qua creditur as opposed to fides quae creditur.

Undoubtedly, some of the very first faith assertions came from followers of Jesus while he was alive, like Mary Magdalene and Peter. As far as we can determine historically, it seems that there was not full agreement between Mary and Peter. Diversity was an unquestionable reality from the very beginning of "Christian" 
articulation of the cause of Jesus. Dissension is also evident in the controversy between James, the brother of Jesus, Peter, and Paul (cf Gl 2:11 ff).

It is clear that some of the earliest faith attestations came from people who probably knew Jesus personally but seemingly, and purposely, did not follow him (e. g. James). On the contrary, their relationships with Jesus were probably strained. According to some canonical (see $\mathrm{Mk} \mathrm{3:21,31-35;6:1-6;} \mathrm{Jn} \mathrm{7:5)} \mathrm{and} \mathrm{extra-canonical} \mathrm{literature} \mathrm{(see}$ the biased tendencies in the Gospel to the Hebrews, fragment 7 - Painter 1997:184), it seems that not only Jesus' brother James but probably other family members as well were among these people. Other faith assertions came from people who never knew Jesus, such as Paul. These assertions, in turn, became the "entire tradition of Christian witness of which the New Testament is simply a part" (Ogden 1996:249; Ogden here agrees with Marxsen 1969).

In other words, only a portion of the testimony of faith in early Christianity is contained in the New Testament. Does such a remark boil down to relativizing the authority of the Scriptures? Scholars are challenged not to sidestep a clear and definite response to this question. Yet my answer would be "yes" and "no." No, because a reflection on the status of the New Testament could enlighten a distinction between "soft" (i e, tolerable) authority and "hard" (i e, manipulative) authority. ${ }^{3}$ Therefore, it is not a matter of relativizing the authority of the Scriptures but rather of highlighting that aspect which is foundational to its authority. Yes, precisely because the concept of canon has been used as an instrument of power (see Altieri 1990; Chapman 2000:93-97; Ter Borg $1998 \mathrm{a}: 411-423)$ that does not comply with the faith to which it is supposedly witnessing.

\section{3. "DECANONIZATION?"}

Let me be clear, I am not personally propelled to destabilize the Christian biblical canon as such or to replace it with another canon. Nevertheless, I do regard the opening of the

\footnotetext{
3 James Barr (1969:150) refers to the difference between the words "authoritarian" and "authoritative" (cf also Vorster [1980]:128). "Authoritarian" pertains to the expectation that a command should be obeyed, irrespective of its fairness, because it comes from a powerful position. "Authoritative" pertains to the expectation of obedience because adherence to commands is recommendable. Barr (1973:27-29) applies these concepts to "hard" authority and "soft" authority respectively. Nixon (1977:336), in light of this distinction, says: “ $\ldots$ the concept of 'soft' authority will be found not to have made sufficient allowance for human sinfulness and blindness and the true way of the disciple is to wrestle with the saying of the master ["the cause of Jesus" - A G v A] until it can be seen to mean something in his [or her] own experience".
} 
debate about the origins, the nature, the function and the scope of the New Testament canon not only as something inescapable in our present postmodern age, but also as of vital necessity. My understanding of the origins of the New Testament canon has persuaded me that its formation is something very natural. Among all the peculiarities (some endorsable and others quite unacceptable) that influenced the formation of the New Testament canon, the common use, or lack of use, of a particular writing caused it to be either included or excluded. To speak of the New Testament canon, as if there were only one such canon, is not quite correct (see Smith 1998:296-311).

The canon consists of a list of biblical books which is regarded by the church as "Sacred Scriptures." The canonical writings in the Greek New Testament, consisting of twenty-seven books, together with the Old Testament, do not constitute a homogeneous corpus of documents. The approved canon within the Roman Catholic believing community differs from the one accepted by the Eastern Orthodox Christian tradition, and, in turn, from the one used within the Protestant tradition. The fact is that there are different canons within the Christian believing community. At least, one can say, the Roman Catholic Church does not differ from the Protestant tradition with regard to the twenty-seven books of the New Testament. Yet, this fact does not make the case concerning canonicity less complicated. The particular list of twenty-seven canonical books originated in some sense because of the dominant use of such a list by the powerful Roman-based church in the West and the bossy intervention, almost instigation, by the Roman emperor Constantine in the fourth century (see Grillmeier 1979:387; Hoover 1992:4-5).

The hot issue nowadays, on account of historical Jesus research, is whether the biblical canon should be expanded by extra-canonical writings or not. In this regard, we should think about the role of the canon within the life of the church as something in some sense similar to other elements that also play a role in Christian worship. Liturgical conventions like creeds have endured influences, modifications, and changes. The same should be expected with regard to the canon. My conviction is that the faith community itself will decide on these issues by means of its own social dynamics. Scholars should not decide on behalf of the believing community. However, the scholarly community can be of help to the believing community. Scholars should make the concerns with regard to 
the process of canonization known and provide a list of selected extra-canonical writings or fragments thereof. The believing community could then decide whether or not to incorporate the list into or use it alongside the existing canons.

\section{HISTORICAL JESUS RESEARCH}

Historical Jesus research, like any other theological reflection carried out within the Christian believing community, should serve the purpose of relativizing "false supports" of faith (Ogden 1996:248, agreeing with Marxsen 1968b:12, 156f). To have faith in the assertions of faith and not in Jesus, who is God's becoming event, is but one step in the direction of finding justification in oneself. It is to put one's ultimate trust in something solely human and not in faith as such that is always extra nos - coming from beyond oneself, from God who comes to us, according to Christian belief, through the cause of Jesus. Placing trust in oneself erects barriers and "false scandals." The result is being a Christian "culturally," often on the opposite side of Jesus himself. Recent historical Jesus studies demonstrate abundantly that Jesus subverted human cultural arrangements (see Van Aarde 1996:833-849). These arrangements served as "false supports" for living which was supposedly living by and through faith alone, but actually amounted to trusting in things made by human hands. An example of this is the ideology related to the temple in Jerusalem.

A historic consciousness which goes hand in hand with the search for Jesus has sensitized me to look out for the presence of trajectories of faith assertions in the documents of early Christianity. Specifically, a historic consciousness has created in me an awareness that faith traditions do not necessarily correspond to biblical ideas. I refer here not only to those faith assertions that originated in the church in post-Biblical times. I have come to realize that there are also ideas present in the Bible itself that have triggered a trajectory that has not deepened the cause of Jesus, but resulted in alienation from it. Two examples of social phenomena found in and advocated by the canon that cannot be traced back to Jesus of Nazareth are a concept of office with a twisted claim to authority and the submission of women (cf। Tm 2:9-15; Tit 2:5).

Such a historic consciousness is peculiar to the period of the Renaissance in the fifteenth century and the Protestant Reformation during the sixteen century cE. Since the 
period of the Enlightenment in the late seventeenth century onwards, this consciousness has gained a special momentum. However, the discernment that an earlier tradition should to some extent have preference over a later one is already found in the history of the church prior to the Renaissance and the Protestant Reformation. It was actually already present at the time when the New Testament canon originated. Among the various criteria applied during the period from the second century up to the closure of canonization of the New Testament in the fourth century was the notion of "antiquity" (see McDonald 1995:236-239). From this perspective, the twentieth-century Swiss exegete and theologian, Oscar Cullmann (1956:77; cf McDonald 1995:236), states that only the tradition from the period of Jesus' incarnation ("becoming flesh") can claim to be authoritative for the church. This period is often referred to as the "apostolic age."

However, this whole picture changes when the criterion of "antiquity" is seen against the background of our knowledge today. Many writings that were used in the church before the closure of the New Testament canon and that were even included in existing "canon lists" of that time, but were eventually excluded (see Gamble 1985:4656), were in fact written much earlier than some writings that were accepted as part of the New Testament canon. Not only can the criterion of "written by an apostle" not hold water - because we have long known that the "twelve apostles" did not write any of the books of the New Testament ${ }^{4}$ - but an earlier faith assertion is not necessarily more reliable in relation to the cause of Jesus than later attestations (see Best 1979:279, in McDonald 1995:238). Therefore the search for what is foundational to faith (in Latin: ad fontem) should not be a search for old traditions as such. It might be of no help at all since it is possible that a present-day sermon could be more foundational to faith than earlier faith assertions.

However, this does not mean that in a post-Aufklärung period one can escape the demand to think historically. To discern what could be seen as the "ground" of faith, one needs to distinguish the "proclaiming Jesus" from the "proclaimed Jesus", though these two aspects are dialectically intertwined. In other words, one can differentiate, from our

\footnotetext{
${ }^{4}$ See Davies $(1994: 110,128,156,185)$ for the Papias tradition with regard to the "apostolic" authorship of the four canonical gospels, and Kümmel (1970:62-97) for Luther's insight that "apostolicity" cannot be taken literarily.
} 
modern perspective, between the elements within the gray area of the interrelatedness of the Jesus traditions and the post-Easter faith attestations, but in most instances they cannot simply be separated. To differentiate in order to challenge the trustworthiness of a particular faith assertion is to be involved in a historical-critical endeavor. Martin Luther taught us that it is not only the traditions of the "post-apostolic" church that should be historically scrutinized, but also the "apostolic" witnesses within the Bible itself. For Luther, it is a search for the root of faith. He referred to the search for the "fountain" as a search for Christ (in German: "Was Christum treibet"). ${ }^{5}$

\section{6. "WAS CHRISTUM TREIBET"}

I am convinced that what Luther meant with his "Was Christum treibet" concept is similar to what die Sache Jesu ("the cause of Jesus") means to me. My justification for this opinion is my understanding of how Luther employed "apostolicity" as a criterion for canonicity. According to him, one should not relate the "apostolicity" of New Testament writing to the view that one of the twelve apostles wrote it bookishly in a verbatim fashion. The concept "apostolicity" should rather be interpreted materially (in German: "sachlich"). In other words, the authority of a canonical document is not that it was strictly written, in the verbatim sense of the word, by an eyewitness of Jesus, or by one among the "twelve apostles" or by a "translator" of one of them (see Kümmel 1970:6297).

Authority is rather based on the fact that the writer of a canonical document is a reliable transmitter of the gospel of Jesus. Luther had in mind the traditio behind the Scriptures. I refer to this "traditio behind" as God's becoming event in Jesus which is articulated in the kerygma. The conduits of the kerygma should reversibly be traced in the faith assertions by transmitters of the Jesus event (cf Kümmel 1970:76-77). Willi Marxsen (1970:236) puts it as follows: "Wenn wir nach der Kanonizität fragen, dann haben wir es zu tun mit dem Problem der Übertragbarkeit der Autorität."

5 Luther, M 1522 WADB 7:382, p. $27=$ [1963] 1990, p. 63. [= "Vorrede auf die Episteln S. Jacobi und Judae," WADB 7 = Luther Deutsch, Die Werke Luthers in Auswahl, Bd.5.: Die Schriftauslegung, herausgegeben von Kurt Aland]. 
What is at stake is a dialectic togetherness of an "early authority" ("frühe Autorität") and a "deduced norm" ("abgeleitete Autorität") (see Marxsen 1970:238). This dialectic is found within the New Testament (and, for that matter, within any faith assertion). The determining norm is referred to in Latin as the principium canonicitatis ("the principle of canonicity") (cf Du Toit [1978]1984:99-108). For Christians, it is the very first aspect of what the authority of the Scriptures ought to be. This foundation is the Jesus event, God's becoming event for humankind. This event is the cause of Jesus and it precedes the kerygma of the church, although it goes dialectically together with the kerygma.

Everyone knows that at the time when Luther, or Paul for that matter, lived and wrote, the distinction between the "historical Jesus" and the "kerygmatic Christ" had not been made. In other articles I have demonstrated that such a contrast serves to emphasize either a continuity or discontinuity between the Jesus event and the kerygma of the church as manifested within the canon (Van Aarde 2000) or in the "post-apostolic" ecclesiastical traditions and creeds (Van Aarde 1999). However, Luther's concept of the "search for Jesus Christ" (Was Christum treibet) expresses exactly the same idea. It is therefore debatable whether this Lutheran concept can be seen as something that amounts to a "canon-within-the-canon" (contra Alexander Schweitzer 1863:165; cf Du Toit 1984:281). The concept "canon-within-the-canon" presupposes reductionism in the sense of "emaciation of the canon" (Adriaanse 1998:320). Luther ranked some New Testament writings (James, Hebrews, Jude and Revelation) not among the "rechten, gewissen Hauptbücher", but "the Reformers have stuck resolutely to the letter of Scripture and they have not even gone so far as to exclude one single writing from it" (Adriaanse 1998:320). Luther's "criterion [Was Christum treibet] drawn from theological content is applied critically by Luther and Calvin to the extant list. So with them, to put it paradoxically, the canon leads to canon criticism" (Adriaanse 1998:319). One would therefore agree with Marxsen (1968c:282-284) that Luther's principle of canon criticism is inadequately described by the Swiss dogmatist Alexander Schweitzer (1808-1888) as "canon-withinthe-canon", but more accurately with the expression "canon-behind-the-canon".

I do not dispute the reality that "some books within the canon have had a more influential function in shaping the expression of the church's faith than have others within 
the canon" (Collins 1983:39; cf McDonald 1995:247). It is also an unquestionable fact that Bible readers operate, consciously or unconsciously, with a "canon-within-thecanon" by focusing on some writings more than on others (see Pelser 1988:391). I only disagree that a discussion of a "canon-within-the-canon" was the intent of Luther's notion of "Was Christum treibet."

Moreover, there is a risk in making peace with the notion of a "canon-within-thecanon" too easily. The risk is one of reductionism and the subsequent inclination to intolerance of the diversity of faith assertions in the canon. In other words, diversity does not disturb me. Diverse thinking about the meaning of the Jesus event is not problematic as such. Rather, what is problematic is that a particular thinking can cause alienation from the cause of Jesus. Luther tolerated diverse faith assertions, but he did not hesitate letting the critical light of God's justifying event in Jesus fall upon the attestations of faith which are to be found both in the Bible and in Christendom. The Jesus event is firmly placed in the forefront.

This contention is adequately expressed by Willi Marxsen as the "canon-behindthe-canon." The grammatical preposition behind in this expression alludes, according to Marxsen (1968c:282-284), to both a material and chronological priority (cf Devenish 1992:xii, in Marxsen 1992). For me, the search for Jesus is not only a historical investigation into the sources behind traditions in order to be challenged by the cause of Jesus, but it is also a consideration of the possibility of overstepping the boundaries of divergence.

Luther's foreword to his interpretation of the Letter to James (my translation and additions) is still very helpful: ${ }^{6}$

All divinely inspired ["rechtschaffenen"] and sacred books ... accord with one another in the sense that they in unison proclaim Christ and search for him ["Christus predigten und treiben"]. Furthermore, this [searching and

\footnotetext{
6 Luther ([1522] 1967:177-178, in Strathmann 1970:42): "Darin stimmen alle rechtschaffenen heiligen Bucher überein, daß sie allesamt Christum predigen und treiben. Auch ist das der rechte Prüfstein, alle Bücher zu tadeln, wenn man sieht, ob sie Christum treiben oder nicht, sintemal alle Schhrift Christum zeigt, Röm 3,21, und St. Paulus nichts denn Christum wissen will, 1.Kor 2,2. Was Christum nicht lehrt, das ist noch nicht apostolisch, wenn's gleich St. Petrus oder Paulus lehrte. Wiederum, was Christum predigt, das wäre apostolisch, wenn's gleich Judas, Hannas, Pilatus und Herodes tate" (my emphasis).
} 
proclaiming] constitutes the sound yardstick ["rechte Prüfstein"] according to which one can dismiss [or designate] those [writings] when one sees whether they focus on Christ alone or not ["Christum treiben"] .... If it does not communicate Christ - whether a teaching from saint Peter or Paul - it is not apostolic. Contrariwise, that which communicates Christ, is apostolic, even if it comes from Judas [Iscariot, who betrayed Jesus], Annas [the father-in-law of Caiaphas, the high priest, who put Jesus to trial], Pilate [the Roman governor, who had Jesus crucified] or Herod [Antipas, king of Galilee, who ridiculed and mocked Jesus as a king].

That Luther filled his search for Christ with the notion of justification by faith alone should not confuse us. We know that this disposition comes from Paul (see Rm 1:17) and that Paul was not personally acquainted with the historical Jesus. For me, this is a clear example that the search for the cause of Jesus does not necessarily mean an identification of the precise words of the historical Jesus (in Latin: ipsissima verba Jesu). However, I do not know of a more concise summary of the subversive wisdom expressed by the cause of Jesus than Paul's words in Romans 1:17 (cf also Jüngel 1962:266)! This verse reads: "For the gospel reveals how God puts people right with God: it is through faith from beginning to end." Wilson (1984:11-12) refers as follows to this material relation between Jesus and Paul:

The basis for critique of the law in Jesus and Paul is often thought to be their common conviction that the relationship between man and the divine rests solely on the character of God - a stern judge but also a gracious, loving and forgiving Father who welcomes the penitent sinner. Of course, this appears in Jesus' teaching in the form of parables and aphorisms while in Paul it is part of a more complex scheme of salvation, and it is clear that Paul works with a more pessimistic view of human nature and indeed of creation as a whole [cf Kümmel (1939) 1965:102]. Yet, it is argued, the core conviction remains the 
same. Bultmann goes to some lengths to defend this view, ${ }^{7}$ and it is one of the impulses behind the somewhat eccentric argument of Jüngel [and of mine - see Van Aarde 2000:557-563] that the theme of justification in Paul is the necessary and inevitable explication of Jesus' preaching of the kingdom.

Theologians who specialize in Luther's thinking therefore correctly refer to Luther's rediscovering of the "canon-behind-the-canon" ("Kanon des Kanons") (see Strathmann 1970:41; Gloege 1970:26; Maurer 1960:47-77). Furthermore, in the search for Jesus, canonical writings do not have precedence over other faith assertions, ${ }^{8}$

To see the New Testament as only a part of the Christian tradition is not only a matter of sound historiography, but also a matter of loyalty to what is foundational to faith, namely the cause of Jesus itself. The cause of Jesus is the proclaiming Word to be found within the Scriptures ("das in der Bibel sprechende Wort"). To me, the cause of Jesus is the canon-behind-the-canon, the "cradle of the church" ("Mutterschoß der Kirche"). In other words, what is authoritative for a Christian is not the assumption of an "infallible" Bible, an "infallible" church or the "inherent" rationality of the human mind (cf McAfee Brown 1978:62-64). The authority to which the Scriptures witness, lies

\footnotetext{
7 Bultmann ([1928] 1969:230) formulates as follows: "It is clear that Jesus did not present this kind of explicit theological reasoning. But it seems to me equally clear that by it Paul simply explains and clarifies the thought of Jesus by the use of specific historical antitheses. The reasoning is certainly based on the same fundamental motive, which was the foundation of Jesus' polemic: the opposition between legal right and the true will of God. That opposition is the reason for Jesus' polemic; God's will cannot be enshrined in legal enactments which man can discharge, so that he could exhibit his achievements before God and present a claim... What Jesus does not state is that from the beginning it is impossible for the law at any time to confront [humankind] who desires to gain security by his own achievements in any other way than his 'custodian'. But however remote this theological idea may be from Jesus' preaching, that preaching does actually imply it. This can be recognized in the fact that Jesus sees and says the officially religious, the 'righteous', are not willing to listen either to the Baptist's call to repentance or to his own, while the tax-collectors and harlots, the 'sinners', listen (Matt. 21.32; Luke 7.29)" (Bultmann's emphasis).
}

${ }^{8}$ Adriaanse (1998:320) says the following with regard to Luther's dictum "Christum treibet": "Still, if we want to find some clue of it in the present context, then we might think of the dictum of Martin Luther which 1 just quoted. The idea of a canon in the canon [sic] does not only imply that non-canonical stuff can be contained in the canon, but also that truly canonical materials can be found outside the canon: for example, assertions about Jesus Christ by people who are not particularly known as prophets and apostles. This example opens the door for nearly every preaching of Christ, all the more so because it does not refer to written, but to oral communication. To be completely honest, with Luther this consequence is merely theoretical. With Calvin too. Still, the idea that the canon, if not in fact then at least in principle, is open to expansion is not alien to the Reformers, let alone to present day protestant dogmatics."

${ }^{9}$ Gloege (1970:25) notes that "Luther (versteht) das in der Bibel sprechende Wort [= Jesus Christ] als den Mutterschoß der Kirche" (my emphasis). 
in its appeal that the believer's words and deeds should concord with Jesus' cause. This applies to one's own life and to biblical writers whose assertions direct the believer's life.

\section{POSTMODERNITY}

We, in the Christian faith community, are used to the list of the twenty-seven books in the New Testament canon as the "authoritative" attestations by which we direct our life. We are used to this canonical list in the same way that we have become used to God-talk in an ontological fashion. These ontological doctrines are open for revision as time passes. In the same way, too, the nature of the existing canon could be revised. When a different thinking cap is put on because of a shift in a paradigmatic mind-set, the notion of canon changes too. This happened during the Protestant Reformation; why should it not happen again in the current postmodern era?

I have defined the age of postmodernity as offering the opportunity for a selective departure from a previous set of values, almost of a systemic nature (Van Aarde 1995:2728). In other words, we now have the insight to depart from those values that underlie modernization and have caused the destabilization of our understanding of what it means to be human. Egocentric rationalism and materialism prevent us from seeing others as people in their own right, and the canon is used as a manipulative instrument to misemploy the Jesus kerygma by coercing others into a certain mind-set and culturally defined way of acting. From the perspective of a typical "monocultural" worldview, the Bible is misused to silence divergence within the Bible, within Christendom, and within the world. We are now very much aware that we live in a plural society, meaning that nowadays we are more aware than in the past of differing opinions within the Bible, as well as within the community of believers and the broader community. We are more aware of the dynamics of canonization. We now have better insight into the social process of ostracizing unacceptable people and shifting them to the periphery of seciety because they jeopardize the ideology of unity with their ideas. We are also now aware how these marginalized people are silenced by means of the codification of canons of particular convictions (see Vos 1998:351-370).

Canonization processes do not result only from divine inspiration but from human endeavor to seek and maintain power. Ter Borg (1998b:69) puts this insight as follows: 
Veel onderzoek naar canon-vorming in de Christelijke kerk betreft de inhoud van de canon: welke onderdelen werden waarom toegevoerd of afgevoerd. Wat was daarna de status van de apocriefen boeken? De redenen, die men voor bepaalde selecties heeft, kunnen van theologische aard zijn. Daarachter ligt dan vaak weer een strijd om overtuigen. Een dergelijke strijd om overtuigenen is vaak ook een strijd om de macht. $Z$ o wordt duidelijk: Wat een canon allemaal ook mag zijn, het is ook een sociaal verschijnsel. Dit betekent dat aan de canon, en aan canon-vorming niets menselijks vreemd is en dat alle feiten en alle mooie dingen, die het menselijk samenleven gewoonlijk aankleven, ook daarin zijn terug te vinden.

At issue is the difficulty of having the words of the "true prophet" alongside those of the "false prophet." As is the case with all human activities, there is also a dark side to the process of the codification of canons. This does not mean that God's revelation has not also been transmitted, among other ways, through the words and deeds of "prophets" and "apostles," and the documents they inspired. Nevertheless, this process paradoxically remains a human activity. In some sense, and to some extent, canonization has to do with coercive power that accompanies domination by means of knowledge. The people who were responsible for the establishment of canons were the ones in powerful positions who had access to "knowledge." It is therefore possible to look at the origins of the biblical canon from another angle than only that of divine inspiration.

The formation of the canon of the Old Testament took place in the time after a shift occurred from a society based on horticulture to one that was agrarian. During the horticultural period, people lived on uncultivated plants and hunted. Agrarian societies came into existence because of the invention of the plow, the control of animal power, and the replacement of wooden utensils by iron plowshares (see Lenski et al [1970] 1995:84-85). The rise of conquering states and the steady replacement of unsophisticated barter by an increase in marine trade and urbanized merchandise, facilitated the movement of people and goods. In other words, agrarian societies can be distinguished from simple societies based on horticulture by their use of an implement with a thin flat metal blade, the hoe, for cultivating the land and loosening the earth around the plants, and by the phases of terracing, irrigating, and fertilizing, as well as traveling with sail 
boats (see Lenski et al 1995:177). They are different from modern industrial societies in the sense that since the industrial revolution, raw materials have been used for much more diversified purposes, while the sources of energy have become quite different and the tools far more complex and efficient (see Lenski 1966). This process reached its zenith during the advanced agrarian society which commenced round about 500 BCE. By the time of Jesus, advanced agrarian societies:

\begin{abstract}
were firmly established in the Middle East, throughout most of the Mediterranean world, and in much of India and China. Within the next thousand years the advanced agrarian pattern spread over most of Europe and much of southeast Asia and expanded further in India and China. Still later it was transplanted to the European colonies in the New World. Advanced agrarian societies still survive in hybridized form in much of Asia, the Middle East, and Latin America, where they constitute the majority of the problemridden, underdeveloped nations of our day.
\end{abstract}

(Lenski 1970:251)

Cultural anthropologists have demonstrated, from a macro-sociological perspective, that the shift from a horticultural (7000-3000 BCE) to an agrarian society (3000 BCE-1800 CE) was accompanied by the emergence of world religions, the process of urbanization, the growth of conquest states, the increase of inequality in social stratification, and the increasing scarcity of resources. Simultaneously, writing and money were invented as media for the control of scarce resources through power and the unequal distribution of authority. Scarce resources can be material goods: food, housing, land, and income, as well as non-material resources: values, status, domination over territory, honor, and prestige (cf Coser [1956]1964:8; 1968:233).

The origins of the Old Testament canon, in particular, can be traced back to postexilic, Judean functionaries (scribal, priestly activities) distinguishable from (aristocratic) political strongmen, as can be seen in the record in the book Chronicles of priests such as Ezra and statesmen such as Nehemiah. We have to remember that it was the "cream" of the Judean people that had been taken into the Babylonian exile. However, these 
functionaries attained limited autonomous power and authority. As retainers of the governing class, they remained dependent on the grace of the governing class and as mediators between the elite and the lower classes they sought popular acceptance among the lower classes. For example, in Greco-Roman Palestine, the Sadducean priests and scribes were the retainers of the (Jerusalem-centered) Hasmonean nobility. Those who belonged to the Pharisees sought a coalition with the (Galilean-centered) Herodian dynasty (cf Freyne 1988:48 and 139). However, at times there were also exceptions to the rule, for example during the reign of the Hasmonean monarch Salome Alexandra. She temporarily favored some Pharisees with authoritarian status within the Jerusalem cult, a deed that resulted in tremendous conflict between the Sadducees and the Pharisees that still echoes years later during the lifetime of Jesus (cf Saldarini 1988:234). The (Hasmonean) Jerusalem authorities competed with the Herodians for the favor of the Roman emperor and his delegates.

There was no middle class in agrarian societies. There were only the elite (the governing class and their retainers) and the peasant class, which included the "impure" expendables for whom society had no place (cf Lenski 1966:280-284). The "top dogs" made up about ten percent of the population (the "rulers" three percent and their "retainers" seven percent) and the "underdogs" about ninety percent. The latter percentage almost exactly coincides with the number of people who were illiterate (see Harris 1989:9; Millard 2000:154-155).

Drawing on present-day theories about the coercive power of knowledge employed by people with authority (see Meynell 1989:419-432), ${ }^{10}$ the following generalized probable scenario regarding the ideologically conditioned origins of the Old Testament canon might be discerned: scribes tried to influence the illiterate lower classes by means of the compilation of a "canon" of sacred writings, by setting up schools in order to interpret these texts, and by providing an education through which their ideology (an articulate reflection on a particular transcendent and immanent value system) could

10 The title of Meynell's study is: "On knowledge, power and Michel Foucault". Johann Beukes (2000:103) refers as follows to Foucault's notion "archaeology of knowledge": "Die winspunt van Foucault se kennisargeologie is dat ons op grond daarvan bewus kan raak van historiese konfigurasies van mag en onder die indruk gebring word dat iemand, êrens, se belange deur een en elke diskoers gedien word. Hy roep ons daartoe op om institutisies (?) te evalueer in terme van die konfigurasies van mag onder die allure van 'normaliteit' en selfs 'wenslikheid."' 
constitute a frame of reference among the masses that agreed with the symbolic and social world of the elite.

An "ideology" often manifests itself in an articulation and codification of values that serve as a program, for example a "charter" (Dahrendorf 1959:185). Manifest interests "are always realities in the heads of the occupants of positions of domination or subjection" (Dahrendorf 1959:178-179). Values, ideologies, and norms as "articulated interests" are maintained and enforced by the "laws" of those in power. Control over scarce resources and the unequal distribution of power and authority are interconnected (Dahrendorf 1959:165). The difference between power and authority is that power is related to a social position by means of which one can carry out his or her own will despite resistance, whereas authority is a legitimate relation of domination and subjection in that a command with a given content will be obeyed by a given group of persons. ${ }^{11}$

Different groups and coalitions in first-century Palestine competed for authority that was unequally distributed by the governing class, and for honor in the eyes of the peasants. The emerging conflict between the various groups (Pharisees, Sadducees, and Essenes) was a manifestation of a power struggle to control the important social symbols within the Second Temple Israelite period, of which the temple was the most influential. The temple was not only the seat of the political strongmen but it was also the economic center (cf Horsley \& Silberman 1997:75). ${ }^{12}$

Writing and money went hand in hand in the advanced agrarian society (see Jamieson-Drake 1991:35, 37; Lenski et al 1995:184). ${ }^{13}$ The images and inscriptions on

\footnotetext{
11 As a point of critique of Karl Marx, Dahrendorf (1959:172-173) considers the distribution of authority, rather than property, or even social class and status, as the ultimate cause of the formation of conflict groups.
}

12 "Thus we come to the great paradox of the Temple: in order to enshrine the idea of the Covenant directly between the people and God, a huge bureaucratic organization had arisen at the central cult place, maintained by a vast civil service of scribes, administrators, accountants, service personnel, Temple officers, and high priestly families who were all dependent on the Temple revenues for their support. According to the Torah, the Temple tithes and offerings were meant to ensure God's blessing for the country's agricultural bounty. Yet they also placed a significant economic burden on the rural population when other taxes and tribute were also in place. And when the priestly hierarchy was seen living in luxury and passively acceding to the demands of the ungodly Romans by authorizing a daily sacrifice for the wellbeing of the emperor (as was the practice since the beginning of direct Roman rule in Judea), there must have been a question in the minds of many of the People of Israel about which of the Temple's aspects the covenantal or the oppressive - was the dominant one" (Horsley \& Silberman 1997:75-76).

13 Jamieson-Drake (1991:35, 37) sees writing as an instrument of control: "In the first place, we would expect writing to function in a context of administrative control, whether economic, social, or political." 
theological questions the Scriptures function as proof text or first principle" (Richard 1981:70). And it is exactly this kind of manipulative theology that has been challenged by the search for the historical Jesus. To some extent it is, according to Pheme Perkins (1993:88-89) a "tension between the academy and the church over [biblical] interpretation."

\section{Works consulted}

Adriaanse, H J 1998. Canonicity and the problem of the golden mean, in Van der Kooij \& Van der Toorn 1998:313-330.

Altieri, C 1990. Canons and consequences: Reflections on the ethical force of imaginative ideals. Evanston, IL: Northwestern University Press.

Barr, J 1969. The authority of the Bible. Ecumenical Review 21(92), 135-166.

- 1973. The Bible in the modern world. London: SCM Press.

Beukes, C J 2000. 'n Postmoderne redekritiek vir kerk en teologie. PhD-dissertation, University of Pretoria.

Bultmann, R [1928] 1969. The significance of the historical Jesus for the theology of Paul, in Faith and understanding, I, 220-246. Edited with an introduction by R W Funk, tr by L P Smith. London: SCM.

Carr, D M 1996. Canonization in the context of community: An outline of the formation of the Tanakh and the Christian Bible, in Weiss, R D \& Carr, D M (eds), A gift of God in due season: Essays on Scripture and community. Festschrift for $J A$ Sanders, 22-64. Sheffield: Sheffield Academic Press. (JSOT 225.)

Chapman, S B 2000. The law and the prophets: A study in Old Testament canon formation. Tübingen: Mohr Siebeck. (Forschungen zum Alten Testament.)

Collins, R F 1983. Introduction to the New Testament. Garden City: Double Day.

Coser, L A [1956] 1964. The functions of social conflict. New York: Free Press of Glencoe.

- 1968. Conflict: Social aspects, in Sills, D L (ed), International Encyclopedia of the Social Sciences 3, 232-236. New York, NY: Macmillan \& Free Press.

Cullmann, O 1956. The early church, ed by A J B Higgins. Philadelphia, PA: Westminster. 
coins were the most available "texts", "readable" by the illiterate masses who were exploited by unbearable taxation (see Fiensy 1991:92-105). Regulations in existing canonical texts provided the codification of this subjection. Canonization thus functioned as a medium through which illiterate masses were influenced to accept the authority of the "conventional wisdom" of "court prophets and sages." Through canonization, "heretics" were silenced. To some extent it was a matter of Scripture against Scripture:

- the prevalence of ancient Israel and the silencing of Palestinian history (see Whitelam 1996);

- the Northern tradition against the Southern tradition;

- the "true" prophets against the "false" prophets;

- the Samaritan Pentateuch against the Judean Pentateuch (see Zsengellér 1998);

- the Sadducean Torah against the Pharisaic expansion of the law to the prophets and writings (see Carr 1996:37-38, building upon the work of Maier 1882);

- the Deuteronomic "prophetic" literature against the priestly literature (i e "Moses" against “Moses");

- the rabbinical literature against the "heretic writings" (in Aramaic: "sifre minim" see Katz 1984:43-76);

- the emperor cult against Christianity and the burning of "sacred books" of Christians by the Roman Emperor Diocletian at the beginning of the fourth century CE (see McDonald 1995:178-182);

- the "canonical" Roman-based New Testament writings against Gnostic, apocryphal and pseudepigraphical writings;

- dogmas against dogmas, et cetera.

This process of "manipulation" through knowledge appears to have the same kind of dynamic that we find in some of our present-day interdenominational and doctrinal theological debates. Within such a mind-set, the status of the canon is instrumental. It serves as a medium through which "truth" is "proven" and claimed as opposed to "false" proofs and claims. "The normativeness of the Scriptures has been tied in the past to a supernaturalistic understanding of revelation. In this perspective the truth claims and authority of Scripture are conceived in a-historical and dogmatic terms. In any 
Dahrendorf, R 1959. Class and class conflict in industrial society. Stanford University Press.

Devenish, P E 1992. Introduction: The Jesus-kerygma and the Christian theology, in Marxsen, $\mathrm{W}$, Jesus and the church: The beginnings of Christianity, selected, translated, and introduced by P E Devenish, xi-xxxv. Philadelphia, PA: Trinity Press International.

Du Toit, A B [1978] 1984. Kanoniek van die Nuwe Testament, in Roberts, J H \& Du Toit, A B, Handleiding by die Nuwe Testament, Band I, 81-294. Tweede verbeterde druk. Pretoria: NG Kerkboekhandel.

Davies, S L 1994. New Testament fundamentals. Revised edition. Sonoma, CA: Polebridge.

Fiensy, D A 1991. The social history of Palestine in the Herodian period: The land is mine. Lewiston, NY: Edwin Mellen Press. (Studies in the Bible and Early Christianity 20.)

Freyne, S 1988. Galilee, Jesus and the Gospels: Literary approaches and historical investigations. Philadelphia, PA: Fortress.

Gamble, H Y 1985. The New Testament canon. Philadelphia: Fortress.

Gloege, G 1970. Zur Geschichte des Schriftverständnisses, in Käsemann E (Hrsg), Das Neue Testament als Kanon: Dokumentation und kritische Analyse zur gegenwärtigen Diskussion, 13-40. Göttingen: Vandenhoeck \& Ruprecht.

Grillmeier, A 1979. Jesus der Christus im Glauben der Kirche, Band I: Von der apostolischen Zeit bis zum Konzil von Chalcedon (451). Freiburg: Herder.

Harris, W V 1989. Ancient literacy. Cambridge, MA: Harvard University Press.

Hoover, R W 1992. How the canon was determined: How did the church decide which books belong to the New Testament? When was the decision made? The Fourth $R$ 5(1), 1-7.

Horsley, R A \& Silberman, N A 1997. The message and the kingdom: How Jesus and Paul ignited a revolution and transformed the ancient world. New York, NY: Penguin Putnam Inc.

Jamieson-Drake, D W 1991. Scribes and schools in monarchic Judah: A socioarcheological approach. Sheffield: Almond Press. (JSOT Supplement Series 109.) 
Jüngel, E 1962. Paulus und Jesus. Tübingen: J C B Mohr.

Katz, S T 1984. Issues in the separation of Judaism and Christianity after 70 CE: A reconsideration. $J B L 103,43-76$.

Kümmel, W G [1939] 1965. Jesus und Paulus, in Heilsgeschehen und Geschichte: Gesammelte Aufsätze 1993-64, 81-106. Marburg: N B Elwert.

-1970. Notwendigkeit und Grenze des neutestamentlichen Kanons, in Käsemann, E, (Hrsg), Das Neue Testament als Kanon: Dokumentation und kritische Analyse zur gegenwärtigen Diskussion, 62-97. Göttingen: Vanden-hoeck \& Ruprecht.

Lenski, G 1966. Power and pivilege: A theory of social stratification. New York: McGraw-Hill.

- 1970. Human societies: A macrolevel introduction to sociology. New York: McGraw-Hill.

Lenski, G, Lenski, J \& Nolan P [1970] 1995. Human societies: An introduction to macrosociology. Seventh Edition. New York: McGraw-Hill.

Luther, M [1522] [1963] 1990. Vorrede auf die Episteln S. Jacobi und Judae. WADB 7 = Luther Deutsch. Die Werke Luthers in Auswahl, Bd.5.: Die Schriftauslegung, herausgegeben von Kurt Aland. 4.Auflage. Göttingen: Vandenhoeck \& Ruprecht. (UTB 1656.)

Maier, J 1982. Jüdische Auseinandersetzung mit den Christentum in der Antike. Darmstadt: Wissenschaftliche Buchgesellschaft. (EdF 177.)

Marxsen, W 1968a Introduction to the New Testament: An aproach to its poblems, tr by G Buswell. Philadelphia, PA: Fortress.

- 1968b, Die Auferstehung Jesu von Nazareth. Gütersloh: Gütersloher Verlagshaus Gerd Mohn.

- 1968c. Das Neue Testament als Buch der Kirche. Gütersloh: Gütersloher Verlagshaus Gerd Mohn.

- 1969. Der Exeget als Theologe: Vorträge zum Neuen Testament. 2.Auflage. Gütersloh: Gütersloher Verlagshaus Gerd Mohn.

- 1970. Das Problem des neutestamentlichen Kanons, in Käsemann, E (Hrsg), Das Neue Testament als Kanon: Dokumentation und kritische Analyse zur gegenwärtigen Diskussion, 233-246. Göttingen: Vandenhoeck \& Ruprecht. 
Marxsen, W 1976. Jesus-Bringer oder Inhalt des Evangeliums?, in Die Sache Jesu geht weiter, 45-62. Gütersloh: Gütersloher Verlagshaus Gerd Mohn.

- 1992. Jesus and the church: The beginnings of Christianity, selected, translated, and introduced by P E Devenish. Philadelphia, PA: Trinity Press International.

Maurer, W 1960. Luthers Verständnis des neutestamentlichen Kanons, in Die Verbindlichkeit des Kanons, 47-77. Hamburg: Luthers Verlaghaus. (Fuldaer Hefte 12.)

McAfee Brown, R 1978. Theology in a new key: Responding to liberation themes. Philadelphia, PA: Westminster.

McDonald, L M 1995. The formation of the Christian biblical canon. Revised \& expanded edition. Peabody, MA: Hendrickson.

Meynell, H 1989. On knowledge, power and Michel Foucault. HeyJ 30, 419-432.

Millard, A 2000. Reading and writing in the time of Jesus. Sheffield: Sheffield Academic Press.

Nixon, R 1977. The authority of the New Testament, in Marshall, I H (ed), New Testament interpretation, 334-350. Exeter: Paternoster Press.

Ogden, S M 1996. Doing theology today. Valley Forge, PA: Trinity Press.

Painter, J 1997. Just James: The brother of Jesus in history and tradition. Columbia: University of South Carolina Press.

Pelser, G M M 1988. Die kanon in die kanon as hermeneuties-teologiese probleem. HTS 44(2), 388-403.

Perkins, P 1993. Canon, paradigms and progress? Biblical Interpretation 1(1), 88-95.

Pilch, J J 1997. Are there Jews and Christians in the Bible? HTS 53(1\&2), 119-125.

Richard, L 1981. What are they saying about Christ and world religions? New York: Paulist Press.

Saldarini, A J 1988. Pharisees, Scribes and Sadducees in Palestinian society: A sociological approach. Wilmington, Del: Michael Glazier.

Schweitzer, A 1863. Die christliche Glaubenslehre nach protestantischen Grundsätzen, Band 1. Leipzig: Hirzel.

Smith, J Z 1998. Canons, catologues and classics, in Van der Kooij \& Van der Toorn 1998:297-311. 
Strathmann, H 1970. Die Krisis des Kanons der Kirche, in Käsemann E (Hrsg), Das Neue Testament als Kanon: Dokumentation und kritische Analyse zur gegenwärtigen Diskussion, 42-61. Göttingen: Vandenhoeck \& Ruprecht.

Ter Borg, M B 1998a. Canon and social control, Van der Kooij \& Van der Toorn 1998:411-423.

- 1998b. De canon als machtsinstrument, in Jenner, K D \& Wiegers, G A (reds), Heilig boek en religieus gezag: Ontstaan en functioneren van canonieke tradities, 69-80. Kampen: Kok. (Leidse Studiën van de Godsdienst 2.)

Thompson, W M 1985. The Jesus debate: A survey and synthesis. New York: Paulist.

Van Aarde, A G 1995. Kerk en teologie op pad na die derde millennium: 'n Paradigmatiese verskuiwing van middelmatige aard. HTS 51(1), 13-38.

- 1996. Kultuurkritiek, eerste-eeuse kulturele wysheid en die alternatiewe visie van Jesus van Nasaret. HTS 52(4), 833-849.

- 1999. Dekonstruksie van dogma: 'n Eietydse ondersoek na die spore van die leer van die twee nature van Jesus. HTS 55(2\&3), 437-470.

- A G 2000. Die relevansie van die historiese Jesus-ondersoek vir kerklike teologie. HTS 56(2\&3), 549-571.

Van der Kooij, A \& Van der Toorn, K (eds) 1998. Canonization and decanonization. Papers presented to the International Conference of the Leiden Institute for the study of Religions (LISOR) held at Leiden 9-10 January 1997. Leiden: Brill. (Studies in the History of Religions 82.)

Van Wyk, D J C 1999. Jesus die Christus: 'n Hervormde perspektief, in Van Wyk, D J C (red), 20ste eeu Hervormde teologie, 108-119. Pretoria: Sentik.

Vorster, W S [1980]. "Moderne eksegese" van die Nuwe testament - 'n ondermyning van Skrifgesag? HTS 35(1\&2), 119-130.

Vos, H M 1998. The canon as a straitjacket, in Van der Kooij \& Van der Toorn 1998:351-370.

Whitelam, K W 1996. The invention of ancient Israel: The silencing of Palestinian history. London: Routledge. 
Wilson, S G 1984. From Jesus to Paul: The contours and consequences of a debate, in Richardson, P \& Hurd, J C (eds), From Jesus to Paul: Studies in honour of Francis Wright Beare, 1-22. Waterloo, Canada: Wilfrid Laurier Press.

Zsengellér, J 1998. Canon and the Samaritans, in Van der Kooij \& Van der Toorn 1998:161-171. 